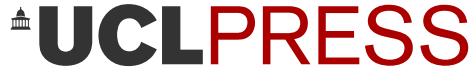

\section{The Journal of the Sylvia Townsend Warner Society}

\section{The Man in the Balloon}

Valentine Ackland*

How to cite: Ackland, V. 'The Man in the Balloon.' The Journal of the Sylvia Townsend Warner Society, 2020, 19(1-2), pp. 25-29 • DOI: https://doi.org/10.14324/

111.444.stw.2020.07

Published: 15 April 2020

\section{Copyright:}

(C) 2020, Tanya Stobbs. This is an Open Access article distributed under the terms of the Creative Commons Attribution License (CC-BY) 4.0 https://creativecommons.org/licenses/by/4.0/, which permits unrestricted use, distribution and reproduction in any medium, provided the original author and source are credited • DOI: https://doi.org/10.14324/111.444.stw.2020.07

This is a reprint originally published in New Statesman (24 July 1954), p. 93.

\section{Open Access:}

The Journal of the Sylvia Townsend Warner Society is a peer-reviewed open access journal. 


\title{
The Man in the Balloon
}

\author{
Valentine Ackland
}

\begin{abstract}
This article puts into the public domain for the first time a correspondence between Valentine Ackland and Elizabeth Wade White written in January 1951. The affair between the two women which had begun in 1938 ended in 1950, although they continued to correspond and occasionally meet until Ackland's death in 1969. The letters were written when both women were struggling to come to terms with the end of their physical and romantic attachment and were deeply unhappy. In the letters each correspondent analyses the history of the relationship and the causes of the fracture between them. The letters and their attachments are remarkable representations of love and guilt, heartache and compassion. Their publication adds to our knowledge of an affair which had repercussions for the lives not only of Ackland and Wade White but also for those of their life partners: Sylvia Townsend Warner and Evelyn Holahan.
\end{abstract}

Keywords Sylvia Townsend Warner; Valentine Ackland; Elizabeth Wade White; life-writing; letters; gay and lesbian studies.

'I wouldn't say that mine has been an uneventful life, really,' said Miss Gribble. Her voice was low-pitched and her manner gentle, so the nurse had some excuse for thinking that the remark was made in deprecation, even that it was a pathetic attempt to look on the bright side; and that was something that the nurse could do well herself. 
'Oh, I'm sure it hasn't!' she answered cheerfully, 'I expect you've seen quite a lot of life in your time, Miss Gribble!'

'But time is so short really, you know,' said Miss Gribble.

The nurse smiled kindly, and there was no edge to her voice as she replied, 'Oh, I don't know so much about that, Miss Gribble. Twenty-four hours feel like quite a long day to us, sometimes!'

Then she was gone, and Miss Gribble let herself slide out into that timeless doze which was now her life.

'Some of them are really interesting, you know,' the nurse wrote in her weekly letter home. 'It's surprising what places they've been to and what they've done. Old Mrs. Pritchard is our star baby just now. She was in Russia when the Revolution broke out (her husband actually talked to the Royal Family just before they were taken prisoner); she's been in Turkey too, and I don't know where. The poor old thing does love to tell us about it all. Even if you only believe half you hear, there's heaps to keep you going without bothering about the pictures; but of course, it doesn't do to take it all as Gospel ...'

Secure in her rest-period, the nurse went on writing home; while Miss Gribble slowly floated inshore again, and came to anchor in her high metal bed. Outside the window the sky was still a pale, cold blue, but there was a look of anxiety about the light. It was growing thinner, it was draining out of some small porous places in the sky; soon afternoon would dwindle into evening.

'Not tea yet?' asked Miss Gribble aloud, and then shook her head. It would not be tea for some time yet. She stretched out her legs and her feet, feeling for an uncrumpled part of the sheet. For a moment the coldness brought her a memory of the feeling of sea-water, of paddling, of the harsh, squeaking silk of sand under a child's bare feet. But it was too far off. It vanished.

Her hands lay outside the bedclothes and she began to pick at the sheet; she smiled. Perhaps if she imitated the action of the dying, she would begin to die? Sympathetic magic, they used to call it. Did she want to die? She shrugged her shoulders. She wanted nothing any more; not even tea; not even death.

Miss Gribble felt very happy as she thought of this; and what a fuss people used to make about this frame of mind. Old disputes, demolishing arguments: 'Isn't it rather negative?' The remembered voice was familiar, but the face, the name of the speaker eluded her. Never mind. It must have been someone very positive, but in those days everyone was positive; she had been so herself. And about so many things! The education of children; which breed of dog was intelligent and which 
insupportable; what must be done to make everyone in the world happy, or good, or rich; who wrote good poetry, and even what good poetry was. She wriggled her comfortable toes and smiled again; what a great deal she knew in those days, and how many things interested her.

Was she bored now? Not at all. She had learned long ago, under tuition of some catastrophe, she couldn't remember which, that as long as one did not look ahead one could not become bored. It was safe to look back, or up or down or around; the only danger lay in looking ahead. Once you knew that, everything was all right. You never saw the Fiend, for he doesn't tread behind you at all; in front is the danger. Strange that Coleridge did not know that. Perhaps he was thinking of a different race of Fiends.

Her own voice came to her ears, 'I wouldn't say that mine has been an uneventful life-' and the poor nurse had thought the remark was made to her, and she had been so kind about it. But, dear me! thought Miss Gribble, I suppose she would think my life dull. And yet ...

Time does go past so quickly. Fifty-four years ago I married Peter. Fifty years ago I left him, and dug myself back into my old identity, not knowing that you could not start again. If the child had lived it would have been fifty-three by now. I should have a daughter, a granddaughter, and probably a great-grand-daughter.

'Here's someone to see you, great-grand-mummy!' nurse would say; and she would feel so touched by that atrocious phrase that tears would be in her eyes, poor child; but she would be glad to believe me so happy. And yet I should not be any happier than I am now, scarcely indeed so happy, if it were like that. But that is not to belittle the anguish I felt when I lost the baby. Never, never belittle anguish; and never belittle joy or pleasure. Then they stay with you; and you can die very well.

Miss Gribble smoothed the sheet beneath her chin and closed her eyes. Behind their lids she saw several strange objects slipping past: a gleaming copper-kettle; a small, bright blue cat; a large and expensive crocodile-skin bag; four cherries ... She wondered whether everyone saw such things when they first closed their eyes. It would not do to inquire now; that kind of question is treated as a wandering of the wits, when you are old and bedridden; questions must be asked, if ever, while you are still formidable, still young. And how far her brain had wandered then, when she was young! If anything is sad in old age, it is the little daily walks the brain takes; along the same little paths to the same pretty views, and back again. But why 'sad,' after all? Sometimes, even now, she could think again what she had astonished herself by 
thinking when she was young: when she was twenty, for instance. She remembered clearly the turn of the lane, the look of the white blossom along the hedge in front of her. She had thought then: 'Perhaps a worm's-eye view is not really any more restricted than a god's-eye view. Perhaps - seeing as far as it can, all that is within its scope, and to scale-the worm sees exactly as much; no more and no less. The worm,' she had thought, 'sees as much as a god sees, or an eagle, or a man in the basket of a balloon.'

Miss Gribble was delighted to have remembered this; and how pleasant and generous to have that lane and the white blossom thrown in as a make-weight. Such a long, leisurely lane it had seemed, going up and down, across two high ridges, and at last, as a grass-track merely, leading right to the edge of the sea.

The astonishing thought led her on and on: for supposing that the worm really did see as much as the eagle, or the man in a balloon, then perhaps this was an example of a universal Law. Perhaps every man and woman alive had the same totality of happiness, hardship, sorrow, pleasure; and when one flinched from the sight of a blind beggar, or of a rich old gentleman who collected valuable pictures, painted by artists who had died unrecognised-perhaps one was troubling oneself about nothing, and the beggar had as much pleasure from his street-corner cup of tea as the rich old gentleman had from whatever he was drinking that afternoon. But here-just as it had done when she was twenty-a sharp, rebellious bramble, trailing from the smooth hedge bordering her walk, whipped round her ankle and nearly brought her down. The dead artists-what about them? They, one must remember, one could never for long forget, they died unrecognised. How was the equal justice demonstrated there?

But she had been twenty then. Now she was old, she was bedridden, she was past the time for bothering, and she would not bother.

Her eyes were still closed. She turned her attention to the little colour-pictures which went on tirelessly, passing across the screen behind her eyelids. The head of a chessman, the black knight; a small, rolling object, darkish grey and shining, with a round bright eye-a seal, perhaps? It was gone before she could be sure; and there was immediately a very ugly brass lamp wearing a pink silk shade; and then the round, vacant, good-natured face of a Beefeater, and his gold-laced chest ... Miss Gribble laughed.

'Were you having pleasant dreams?' A young probationer had brought her tea, and after putting down the tray she stood for a moment 
beside the bed. 'You always do seem so cheerful, Miss Gribble,' she said timidly, 'I think it's wonderful, I do, really.'

In the two or three seconds between the girl's entry and her remark, Miss Gribble had slipped her moorings again and was moving rather fast out to sea. But she hauled back with an effort, and opened her eyes; meeting an earnest, gentle regard.

'I am very comfortable,' she said, finding it difficult to speak aloud; but she gathered her wits carefully and added with scarcely a pause, 'And that is really very much like being happy, when you are old.'

But the girl looked taken aback, and Miss Gribble strove to hold to the shore long enough to make herself intelligible. She understood that the girl was afraid; afraid that she might be made suddenly unbearably sorry for this poor old woman, so lonely, so near death, who had had, seemingly, so little life. But once she knew how it really was, she would not be afraid at all.

Miss Gribble cleared her throat, put out her hand and took the child's scrubbed paw in a firm grasp. 'I have had a wonderful life,' she said clearly, 'and it is still wonderful. It goes on hour by hour, you know. I am most comfortable. Thank you for my delicious tea.'

With her free hand the girl poured out a cup of tea, and the old woman's clasp relaxed. She let her hand lie on the coverlet and did not notice that her fingers began to fret the sheet. She forgot the young nurse, and yielded herself to the slow pull of the tide that drew her outwards again. But, from her good will and wish to reassure, she went on speaking; such mysterious words that, by reason of that alone perhaps, they did bring reassurance to the girl who listened.

'I have experienced everything, really,' said Miss Gribble's gentle voice, 'and whether I was the worm, or the god, or the man in the balloon doesn't matter. It amounts to the same thing. But I like to think of myself as the man in the balloon.'

New Statesman (24 July 1954), p. 93 